\title{
KEPEMIMPINAN TRADISIONAL JAWA-ISLAM DALAM MASYARAKAT JAWA
}

\author{
Sarjana Sigit Wahyudi \\ Jurusan Sejarah Fakultas IImu Budaya Universitas Diponegoro
}

\begin{abstract}
In Indonesia, especially in Central Java, there are plural societies which need the presence of a leader who fits them best. Therefore, a figure who has the characteristics of leadership which fits the interest of his supporters is needed. The characteristics of leadership offered here are the traditional and Islamic model, including the model of "etika kedzaifan." $A$ figure, tipology, and characteristics which are embedded in the mind of a leader are what the society need.
\end{abstract}

Keywords: leader, figure, type, characteristics, model, development, Javanese society.

\section{Pendahuluan}

Masyarakat Jawa Tengah dan masyarakat Indonesia umumnya membutuhkan kehadiran pemimpin yang selaras baik dengan selera masyarakat pendukungnya maupun kondisi masyarakat yang majemuk. Artikel ini membahas tentang tipologi kepemimpinan dan sifat pemimpin yang sesuai dengan cita rasa masyarakat Jawa Tengah. Harapan terhadap munculnya tipe dan sifat-sifat pemimpin yang ideal pada dasarnya merupakan cerminan dari kerinduan masyarakat terhadap pemimpin mereka.

\footnotetext{
Artikel ini juga membicarakan tentang sifat pemimpin berdasarkan model kepemimpinan tradisonal Jawa dan Islam. Dalam model kepemimpinan tradisional Jawa, khususnya Jawa Tengah, seorang pemimpin ditekankan untuk mengutamakan kerukunan dan hormat kepada Sang Pencipta, leluhur, dan orang tua. Sementara itu dalam model kepemimpinan Islam diterangkan tentang pentingnya sifatsifat pemimpin pasca-Nabi Muhammad SAW, ketika kepemimpinan Islam dipegang oleh para khalifah dan akhirnya terpecahpecah ke dalam kelompok-kelompok, di antaranya yang terbesar adalah Sunni dan Syiah. Kedua kelompok ini mempunyai pemahaman tentang kepemimpinan yang
}

berbeda walaupun keduanya menggunakan sumber yang sama. Hal itu belum termasuk kelompok-kelompok kecil yang lain, misalnya kelompok Islam sekular.

Perbedaan pemahaman mengenai kepemimpinan Islam terasa pula di Indonesia. Sebagian tokoh Islam, salah satunya adalah Abdurrahman Wahid, berusaha meredam perbedaan pemahaman itu dengan menyodorkan solusi tentang bagaimana cara mengatasi masyarakat Indonesia yang plural terutama menyangkut masalah kepemimpinan baik dalam konteks kehidupan bermasyarakat maupun bernegara. Namun dalam perkembangan patut disayangkan bahwa dalam setiap pemilihan pemimpin baik di tingkat desa, kota, daerah maupun pusat telah dinodai dan dikotori dengan penyelewengan, janjijanji manis dalam kampanye, yang disertai praktek politik uang, tidak ditepati setelah seseorang terpilih sebagai pemimpin. Kondisi ini terus berjalan seolah-olah tanpa tersentuh oleh hukum. Lalu, bagaimanakah kerinduan masyarakat kepada pemimpinnya yang diidolakan dan didambakan terutama mengenai tipe dan sifat-sifat idealnya yang melekat? 


\section{Konsep Kepemimpinan}

Membahas kepemimpinan antara lain membicarakan mengenai perihal pemimpin, konsep kepemimpinan, dan mekanisme pemilihan pemimpin. Sebelum membicarakan lebih jauh soal kepemimpinan, ada baiknya dilakukan peninjauan terlebih dahulu definisi konsep pemimpin. Pendefinisian ini dapat membantu kita untuk memahami dan melakukan pembahasan menurut alur yang sistematis.

Banyak definisi tentang pemimpin baik itu menurut ahli politik, ekonomi, sosial, antropologi (budaya) maupun agama. Tulisan ini menyampaikan definisi yang relevan dengan pokok pembahasan. Seorang ahli sosiologi, Soerjono Soekanto, menghubungkan kepemimpinan (leadership) dengan kemampuan seseorang sebagai pemimpin (leader) untuk mempengaruhi orang lain (anggotanya), sehingga orang lain itu bertingkah laku sebagaimana dikehendaki oleh pemimpinnya (Soekanto, 1982a: 60). Ahli sosiologi yang lain, Wahyusumijo, lebih melihat kepemimpinan sebagai suatu proses dalam mempengaruhi kegiatankegiatan seseorang atau sekelompok orang dalam usahanya mencapai tujuan yang sudah ditetapkan (Wahyusumijo, 1984: 60).

Di pihak lain, dalam antropologi budaya, muncul pandangan yang membedakan antara kepemimpinan sebagai suatu kedudukan sosial dan sebagai suatu proses sosial (Koentjaraningrat, 1969: 181). Kepemimpinan sebagai kedudukan sosial merupakan kompleks dari hak-hak dan kewajiban-kewajiban yang dapat dimiliki oleh seseorang atau suatu badan. Sementara sebagai suatu proses sosial, kepemimpinan meliputi segala tindakan yang dilakukan oleh seseorang atau suatu badan yang mendorong gerak warga masyarakat.

Apabila kepemimpinan diartikan sebagai kemampuan seseorang untuk mempengaruhi orang lain sehingga mereka mengikuti kehendaknya, maka seseorang itu dapat disebut mempunyai pengaruh terhadap oarang lain. Pengaruh itu dinamakan kekuasaan atau wewenang. Istilah kekuasaan dalam hal ini merujuk pada kemampuan seseorang untuk mempengaruhi orang atau pihak lain, sedangkan wewenang merupakan kekuasaan seseorang atau sekelompok orang yang mendapat dukungan atau pengakuan dari masyarakat. Dalam hubungan dengan kepemimpinan, Kartini Kartono (1982) mengatakan bahwa kepemimpinan harus dikaitkan dengan tiga hal penting yaitu kekuasaan, kewibawaan, dan kemampuan.

Sementara itu dilihat dari sudut pandang agama (Islam), istilah kepemimpinan berasal dari kata 'pemimpin,' artinya orang yang berada di depan dan memiliki pengikut, terlepas dari persoalan apakah orang yang menjadi pemimpin itu menyesatkan atau tidak. Dalam Islam, setidaknya ada dua konsep penting yang berkaitan dengan kepemimpinan, yaitu imamah dan khalifah. Masing-masing kelompok Islam memiliki pendefinisian berbeda tentang kedua konsep itu, meskipun ada juga yang menyamakannya.

Kaum Sunni menyamakan pengertian khalifah dan imamah. Dengan perkataan lain, imamah disebut juga sebagai khalifah. Bagi kaum Sunni, orang yang menjadi khalifah adalah penguasa tertinggi yang menggantikan Rasulullah SAW. Oleh karena itu khalifah juga disebut sebagai imam (pemimpin) yang wajib ditaati (AsSalus, 1997: 16).

Sebaliknya, kaum Syiah membedakan pengertian khalifah dan imamah. Hal ini dapat dilihat dalam sejarah kepemimpinan Islam setelah Rasulullah SAW wafat. Kaum Syiah bersepakat bahwa pengertian imam dan khalifah itu sama ketika Ali bin Abi Thalib diangkat menjadi pemimpin. Namun sebelum Ali bin Abu Thalib menjadi pemimpin, mereka membedakan pengertian antara imam dan khalifah. Abu Bakar, Umar bin Khattab, dan Ustman adalah khalifah namun mereka bukanlah imam (Amini, 205: 18). Dalam 
pandangan kaum Syiah, sikap seorang imam haruslah mulia sehingga menjadi panutan para pengikutnya. Imamah didefinisikan sebagai kepemimpinan masyarakat umum, yakni seseorang yang mengurus persoalan agama dan dunia sebagai wakil dari Rasulullah SAW. Rasulullah SAW yang menjaga agama dan kemuliaan umat wajib dipatuhi dan diikuti. Imam mengandung makna lebih sakral daripada khalifah. Secara implisit kaum Syiah menganut pandangan bahwa khalifah hanya mencakup ranah jabatan politik, tidak melingkupi ranah spiritual-keagamaan; sedangkan imamah meliputi seluruh ranah kehidupan manusia baik itu agama maupun politik. Seperti halnya kaum Sunni dan Syiah, kalangan Islam sekular memiliki pandangan sendiri tentang kepemimpinan. Konsep kepemimpinan kelompok Islam sekular cenderung mengacu pada kepemimpinan model Barat.

Meskipun kelompok Sunni, Syiah, dan Islam sekular mempunyai sudut pandang yang berbeda mengenai kepemimpinan, ketiganya menunjukkan kesepahaman bahwa suatu masyarakat haruslah memiliki pemimpin. Setiap masyarakat dengan demikian tidak mungkin dapat dipisahkan dari masalah kepemimpinan.

\section{Pemilihan Pemimpin dan Legitimasi Kepemimpinan}

\subsection{Cara Pemilihan Pemimpin}

Derap pembangunan di Indonesia baik di kawasan pedesaan maupun perkotaan sangat bergantung pada kepemimpinan para kepala daerah. Menurut Koentjaraningrat (1980: 201), pemilihan kepala-kepala daerah, terutama di Jawa Tengah, sebagian besar masih memperhatikan faktor keturunan. Kepalakepala daerah yang memerintah pada masa belakangan masih keturunan dari kepala daerah yang berkuasa pada masa sebelumnya. Hal itu dapat dilihat dari dari silsilahnya.

Berdasarkan laporan mengenai struktur pemerintahan desa yang disusun oleh DPRD Jawa Tengah dapat ditarik simpulan bahwa proses pemilihan kepala desa dilakukan oleh suatu panitia di bawah pimpinan camat. Sebagai calon kepala desa atau pimpinan desa, maka realitanya dapat disimak pada kutipan di bawah ini.

Dalam praktiknya, para calon yang dipilih biasanya bukan orang-orang yang memiliki kemampuan tapi orang-orang kaya. Ini disebabkan kebiasaan warga desa memilih seorang calon bukan berdasarkan kemampuan calon itu, melainkan berdasarkan banyaknya pemberian kepada mereka. Ini malahan nampak lebih jelas di desa-desa yang makmur, sehingga pemilihan lurah menjadi suatu gelanggang pertikaian yang ramai sekali. Alasan utama dari konflik itu berpangkal pada tanah bengkok atau tanah lungguh yang diberikan pada calon yang sukses (Koentjaraningrat, 1984: 201).

Dengan melihat kutipan di atas tampak bahwa pemimpin desa dipilih tidak hanya didasarkan pada keturunan, namun juga pada pemberian yang biasanya berupa uang. Para calon kepala desa berusaha melakukan pendekatan kepada para pemilih terutama pada masa kampanye. Tidak mengherankan jika para calon kepala desa pada masa kampanye melakukan berbagai cara dalam rangka mendapatkan dukungan dari warga masyarakat yang memiliki hak pilih. Mereka bahkan tidak segan-segan untuk melakukan praktik politik uang sambil menebar janji-janji manis kepada warga masyarakat agar mau memilihnya. Sudah barang tentu hal ini tidak dibenarkan baik oleh negara maupun agama. Namun demikian praktik semacam itu tetap berjalan dengan lancar dan seolaholah tidak tersentuh oleh hukum.

Sejalan dengan hal itu Sartono Kartodirdjo (1982: 226) menyatakan bahwa latar belakang kepemimpinan dalam masyarakat tradisional ataupun pedesaan dipengaruhi oleh kelahiran, kekayaan, dan status. Sebagaimana dikatakan oleh Prasadjo (1982: 54), latar belakang politik dan agama juga memiliki pengaruh yang penting dalam kepemimpinan di pedesaan. 


\subsection{Asal-usul Legitimasi}

\section{Kepemimpinan}

Pemimpin yang terpilih harus mendapatkan legitimasi dari anggotanya atau warga masyarakat yang dipimpinnya. Seorang pemimpin dapat memiliki wewenang untuk memimpin secara resmi setelah mendapat legitimasi berdasarkan pada prosedur yang telah ditetapkan dalam adat-istiadat atau hukum yang berlaku dalam masyarakat yang bersangkutan. Prosedur itu tentu saja dapat berbeda baik antara masyarakat yang satu dan yang lain maupun dari waktu ke waktu.

Dalam masyarakat tradisional, misalnya, legitimasi atas kepemimpinan seseorang pada umumnya dilakukan melalui rangkaian upacara yang melibatkan kehadiran roh nenek moyang atau dewadewa. Pada zaman kerajaan, prosedur untuk melegitimasi kepemimpinan seseorang dapat dilakukan melalui pemilihan, pemilihan bertingkat atau pemilihan oleh sebagian masyarakat. Wahyu, nurbuat, pulung, ngalamat, dan mimpi juga merupakan unsur-unsur yang berperan penting baik dalam pemilihan pemimpin maupun legitimasi atas kepemimpinannya (Kartodirdjo, 1973: 8).

Oleh karena itu, untuk mendapatkan kekuasaan dalam kepemimpinan, seseorang harus menempuh berbagai jalan (laku) yang panjang. Kekuasaan dapat juga diperoleh melalui keturunan atau lewat kekuatan fisik. Pada zaman modern ini, kepemimpinan dapat pula diperoleh melalui pendidikan dan pemilihan berdasarkan keahlian atau spesialisasi. Untuk menduduki jabatan pada berbagai level tidak lagi didasarkan terutama pada keturunan, melainkan pada tingkat pendidikan formal (Sutherland, 1983).

Calon pemimpin yang berhasil terpilih harus mendapatkan pengakuan dari masyarakat. Masyarakat Indonesia, terutama yang berada di daerah pedesaan, masih mempercayai bahwa seorang pemimpin mempunyai wibawa, wewenang, kharisma, dan kekayaan. Persyaratan ini penting bagi para pemimpin di tingkat kota atau pedesaan, sebab mereka pada masa sekarang atau zaman demokrasi dipilih secara langsung oleh rakyat.

\section{Model Kepemimpinan}

\subsection{Model Kepemimpinan Tradisional}

Jawa lebih mengutamakan prinsip kerukunan dan sikap hormat kepada alam, pencipta, leluhur, guru, orang tua, bangsa, negara, dan agama (Magnis-Suseno, 1985: 36-38). Orang Jawa umumnya juga mengutamakan keselarasan dalam hidup bermasyarakat (Mulder, 1981: 17). Pandangan hidup dan pola pikir yang demikian sangat mempengaruhi masyarakat Jawa dalam meletakkan dasardasar kemasyarakatan dan kebudayaan. Apabila hal ini dihubungkan dengan masalah kepemimpinan, maka seorang pemimpin sedapat mungkin harus mampu memperlihatkan sikap hidup yang sederhana, jujur, adil, bertenggang rasa (tepa selira), hemat, disiplin, dan taat kepada hukum (Koentjaraningrat, 1981: 64).

Berbagai piwulang dan pitutur telah mengajarkan tentang sifat-sifat seorang pemimpin. Ajaran Ki Hajar Dewantara sebagai tokoh pendidikan, misalnya, menyatakan bahwa seorang pemimpin harus mempunyai tiga pilar, yaitu: "Ing Ngarso Sung Tuladha, Ing Madya Mangun Karsa, Tut Wuri Handayani." Demikian pula, kakawin Ramayana dan Mahabarata menyatakan bahwa seorang pemimpin harus memperlihatkan sikap yang merujuk pada ajaran tentang Hasta Bhrata, yaitu mencontoh sikap delapan dewa, di antaranya Dewa Surya, Candra, Bayu, dan Baruna Dewa Air yang antara lain mempunyai sifat sabar. Dalam filsafat Jawa pun terdapat banyak istilah tentang sifatsifat pemimpin yang yang dikenal dengan "empat t," yaitu teteg-sebagai pengayom, tatag-berani, tangguh-kuat, dan tanggonpantang mundur, mrantasi sabarang gawe.

\subsection{Model Islam dan Etika Kedaifan}

Dalam era pascamoderen yang mengagungkan multikulturalisme sebagai 
pandangan hidup, etika kedaifan identik dengan menghargai orang lain (liyan) atau menganggap diri sebagai sosok yang lemah dan membutuhkan keberadaan orang lain dalam menjalani kehidupan bersama yang semakin berat. Kehidupan dalam etika kedaifan, menurut Goenawan Muhammad sebagaimana disitir oleh Triyanto Tiwikromo (2008), sama halnya dengan tidak menganggap orang lain seperti yang dikatakan oleh Sartre yaitu sebagai neraka. Semangat multikulturalisme dan demokrasi menempatkan rakyat sebagai sahabat, kanca, untuk mencapai masyarakat yang aman dan sejahtera (Tiwikromo, 2008: 4).

Dalam pandangan Islam, seorang pemimpin harus mempunyai kualitas spiritual, terbebas dari segala dosa, memiliki kemampuan sesuai dengan realitas, tidak terjebak pada dan menjauhi kenikmatan dunia, dan harus memiliki sifat adil. Adil dalam hal ini dapat dipahami sebagai cara menempatkan sesuatu pada tempatnya yang layak. Penerapan sifat keadilan oleh seorang pemimpin dapat dilihat dari bagaimana caranya mendistribusikan sumberdaya politik, ekonomi, sosial, dan budaya kepada rakyatnya.

Melihat kemajemukan masyarakat Indonesia, maka tantangannya adalah bagaimana cara mengembangkan pluralisme dalam konteks membangun kepemimpinan dan kedaulatan bangsa. Fungsi kepemimpinan adalah sebagai ulil amri dan khadimul ummah, artinya amanah jabatan dan kekuasaan harus digunakan sesuai dengan tuntutan Allah swt dan Rasul-Nya, berlaku adil, dan melindungi kepentingan masyarakat.

Dengan demikian, meskipun Islam adalah agama mayoritas, jangan sampai kepentingan umat Islam mengakibatkan negara lebih banyak melayani kepentingan segelintir orang yang mengusai aparatur negara. Sementara mereka yang berusaha menyuarakan ide-ide demokrasi, pluralisme, dan perlindungan hak-hak asasi manusia cenderung dituding tidak memiliki nasionalisme.

\subsection{Pengembangan Sifat Pemimpin}

Sifat pemimpin harus dikembangkan sendiri karena sifat seseorang berbeda satu sama lain. Kepribadian ikut mempengaruhi sifat dan perilaku kepemimpinan seseorang. Pemimpin harus senantiasa meningkatkan kemampuan, mempraktikkan keterampilan, mencari peluang, dan mengembangkan potensi anak buah. Sebagai pedoman bagi pemimpin adalah "perlakukan orang lain sebagaimana Anda ingin diperlakukan." Dengan cara itu seorang pemimpin berusaha memandang suatu keadaan dari sudut pandang orang lain atau tenggang rasa.

Merujuk pendapat Geofrey G. Meredith, kualitas pemimpin dapat diukur dengan memperhatikan sejumlah hal berikut: (1) yakinkan bahwa dirinya seorang pemimpin, (2) banyak orang yang mencari bapak untuk minta dipimpin atau bertanya, (3) kembangkan dan terapkan ide-ide baru, (4) mainkan peranan aktif dalam kehidupan masyarakat, (5) tingkatkan kekuasaan dan hilangkan kelemahan, (6) tingkatkan program dan rencana tentang kepemimpinan, (7) belajarlah dari kesalahan terdahulu, (8) berorientasilah kepada hasil dan selesaikan sesuatu yang telah dimulai, (9) gunakan kekuatan sebagai pemimpin untuk membantu orang lain, (10) yakinkan orang lain tentang kemampuan, (11) dengarkan masukan, saran, dan nasihat atau kritik sekalipun, dan (12) lakukan perubahan ke arah kemajuan (Meredith, t.t.: 18-21).

\subsection{Hubungan Pemimpin dan Rakyat dalam Pembangunan}

Dalam membicarakan hubungan antara pemimpin dan rakyat dalam pembangunan, perlu dilihat berbagai variabel yang dapat dikelompokkan ke dalam independent variable dan dependent variable. Sebagai independent variable adalah bahwa seorang pemimpin seharusnya mempunyai dasar antara lain mengabdi pada kepentingan umum, memperhatikan rakyat baik di dalam maupun di luar pekerjaan, dan menciptakan komunikasi yang lancar dengan bawahan (rakyat). Dependent variable atau variabel 
yang dipengaruhi meliputi antara lain semangat kerja, displin kerja, gairah kerja, dan hubungan yang harmonis dengan bawahan. Kedua variabel ini akan mempengaruhi keberhasilan kepemimpinan seseorang dalam sebuah lembaga, baik itu di tingkat desa, kota ataupun pusat. Hubungan antara sejumlah variabel yang telah disebutkan di atas dengan keberhasilan kepemimpinan dapat dilihat secara geometrik sebagai berikut.

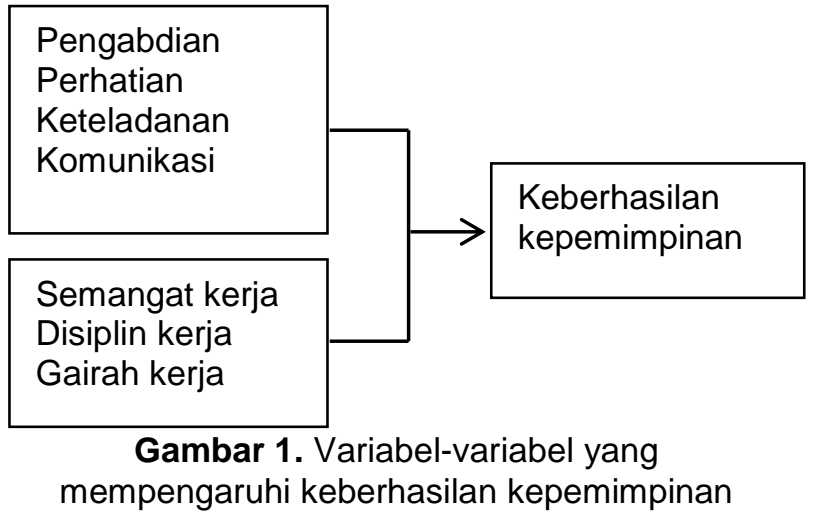

Pendapat lain dikemukakan oleh Kartini Kartono (1982: 31), yang menyatakan bahwa keberhasilan pemimpinan berhubungan dengan pengelolaan kekuasaan, kewibawaan, dan kemampuan. Keberhasilan seorang pemimpin juga dapat ditentukan dari bentuk kerja sama dalam pembangunan yang tidak hanya untuk anggotanya, namun dari masyarakat untuk masyarakat (Syarmani, 1978: iii). Pembangunan di sini dapat diartikan sebagai usaha atau rangkaian usaha pertumbuhan dan perubahan terencana yang dilakukan secara sadar oleh suatu bangsa, negara, dan pemerintah menuju modernitas dalam rangka pembinaan bangsa (Siagian, 1981: 99). Seorang pemimpin harus mempunyai kekuasaan yang bersumber pada hak milik kebendaan, kedudukan, kekuasaan, birokrasi, dan juga kemampuan khusus (supranatural) yang lain daripada orang biasa.

Masyarakat tidak dapat bergerak tanpa adanya pemimipin sebagai mediator dan motivator serta komunikator dalam pembangunan di berbagai bidang.
Pemimpin harus dapat menjalankan ketiga fungsi itu dalam kelompoknya. Dalam struktur organisasi, peran seorang pemimpin tidak ada artinya tanpa dukungan rakyatnya. Hubungan antara pemimpin dan rakyat merupakan hal yang mutlak karena keduanya saling membutuhkan dan saling melengkapi. Hubungan itu dapat digambarkan dengan menggunakan sebuah pepatah Jawa: kaya godhong suruh lumah lan kurebe yen disawang beda rupane, yen dimamah gineget padha rasane.

Hubungan antara pemimpin dan rakyat dapat pula digambarkan sebagai hubungan patron-cilent (patronase), yaitu hubungan antara bapak dan anak. Bapak (pemimpin) berkewajiban melindungi anakanaknya, sedangkan anak-anak harus patuh kepada bapaknya sebagai pemimpin (Koentjaraningrat, 1981: 191). Hubungan antara pemimpin dan anggotanya sering kali bertolak dari kebutuhan anggotanya (Legg, 1983: 21).

Dalam kedudukan sosial, seorang pemimpin berperan mengontrol dan mengawasi serta menggerakkan segala aktivitas dalam masyarakatnya. Pemimpin yang baik akan dianggap oleh anggotanya sebagai cermin, guru, dan tokoh kunci (key person) dalam pembangunan.

\section{Simpulan}

Dalam setiap lembaga termasuk dalam bermasyarakat, berbangsa, dan bernegara selalu dibutuhkan kehadiran seorang pemimpin. Peran (role) seorang pemimpin sangat sentral dan strategis karena ia dibutuhkan sebagai motivator, mediator, dan komunikator dalam pembangunan.

$\begin{array}{ccr}\text { Seorang } & \text { pemimpin } & \text { dalam } \\ \text { menjalankan } & \text { kepemimpinannya } & \text { harus } \\ \text { mendapatkan } & \text { legitimasi } & \text { dari }\end{array}$
masyarakatnya. Sikap pemimpin yang sesuai dengan model kepemimpinan dan sifat-sifat ideal yang dianggap mulia akan menjadikan seorang pemimpin sebagai idola bagi masyarakat yang dipimpinannya. Ada beragam tipe atau model kepemimpinan dan sifat-sifat ideal 
pemimpin, dalam model kepemimpinan tradisional Jawa dan Islam, model kepemimpinan dan sifat-sifat pemimpin itu dipandang lebih selaras dengan kondisi masyarakat Indonesia yang plural dan mayoritas menganut Islam.

Pembicaraan tentang kepemimpinan dan pemimpin yang ideal menjadi penting ketika dihadapkan pada kenyataan bahwa pemilihan pemimpin hampir di semua level pada saat ini telah tercoreng oleh praktik politik uang dan janji-janji yang muluk tetapi tidak ditepati. Kondisi itu pada gilirannya mendorong terjadinya degradasi dan pergeseran nilai budaya dalam masyarakat, terutama menyangkut kepemimpinan. Para pemimpin sudah seharusnya berusaha menjalin hubungan yang membuatnya dekat dengan rakyat. Tanpa rakyat, mereka tidak dapat berbuat apa-apa. Inilah bentuk kerinduan rakyat terhadap para pemimpinnya.

\section{DAFTAR PUSTAKA}

Amini, Ibrahim. 2006. Para Pemimpin Teladan. Jakarta: Al-Huda.

As-Salus, Ali. 1997. Imamah dan Khalifah dalam Tinjauan Syar'i. Jakarta: Gema Insani Press.

Departemen Pendidikan dan Kebudayaan. 1996. Kamus Besar Bahasa Indonesia. Edisi Kedua. Jakarta: Balai Pustaka.

Kartodirdjo, Sartono. 1975. Sejarah Nasional Indonesia. Jilid IV. Jakarta: Depdikbud. 1976. Protest Movement in Rural Java. London: Oxford University Press.

Perke 1982. Pemikiran dan Suatu Alternatif. Jakarta; PT. Gramedia.

Kartono, Kartini. 1982. Pemimpin dan Kepemimpinan. Jakarta: Rajawali.

Khomeini, Imam. 2002. Sistem Pemerintahan Islam. Jakarta: Pustaka Zahra.

Koentjaraningrat. 1979. Pengantar IImu Antropologi. Jakarta: Aksara. 1980. Beberapa Pokok Antropologi. Jakarta: Balai Pustaka.
1984. Kebudayaan Jawa.

Jakarta: Balai Pustaka.

Legg, Keit R. 1983. Tuan Hamba dan Politisi. Jakarta: Sinar Harapan.

Meredith, Geofrey G.. t.t.. Kewirausahaan: Teori dan Praktek. Jakarta: PPM.

Prasojo, Budi. 1982. Pembangunan Desa dan Masalah Kepemimpinnya. Jakarta: Yayasan IImu-ilmu Sosial.

Rakhmat, Jalalaludin. 2003. Filsafat Politik Islam antara Al-Farabi dan Khomeini dalam Rahmaini. Bandung: Mizan.

Siagian, Sondang. 1981. Administrasi Pembangunan. Jakarta: Gunung Agung.

Soekanto, Soejono. 1982a. Sosiologi Suatu Pengantar. Djakarta: PT. Radjawali. 1982b. Teori Sosiologi tentang Pribadi dalam Masyarakat. Jakarta: Ghalia Indonesia.

Subagyo, Rahmat. 1981. Agama Asli Indonesia. Jakarta: Sinar Harapan dan Loka Cipta Caraka.

Sumiyo, Wahyu. 1984. Kepemimpinan dan Motivasi. Jakarta: Ghalia Indonesia.

Sutherland, Heather. 1983. Terbentuknya Sebuah Elite Birokrasi (diindonesiakan oleh Sunarto). Jakarta: Sinar Harapan.

Syarmani, Abdullah. 1978. Pembangunan Partisipasi Masyarakat dalam Pembangunan Pertanian di Pedesaan dalam Repelita III. Jakarta: Agro Ekonomi.

Tiwikromo, $\quad 2008$. "Kepemimpinan Jawa dalam Masyarakat Kotemporer," makalah disajikan dalam Seminar Budaya untuk Memperingati Hari Jadi Kota Semarang ke-461 di Gedung Balaikota Semarang, 17 Mei 2008. 